\title{
Inventory, Identification, and Analysis of Randai Performing Arts Elements for the Development of Minangkabau Theatrical Dance
}

\author{
Tulus Handra Kadir ${ }^{1}$ \\ ${ }^{1}$ Universitas Negeri Padang, Padang, Indonesia, $ه$ (email),tulushandra@gmail.com
}

\begin{abstract}
This article describes the inventory, identification and analysis of elements of Randai performing art for the development of the Minangkabau theatrical dance based on Randai in the context of developing the Minangkabau performing arts. The development of contemporary performing arts, Randai and Minangkabau dance are not able to compete with modern performing arts. On the other hand, Randai has elements of performance that can be used in the development of theatrical dance, as a new form of Minangkabau performing art that combines elements of Randai and dance in Minangkabau. It is expected to be able to keep abreast of developments of contemporary performing arts. Development is based on research conducted qualitatively (the first phase of research) and experimentally (the second phase of research). Qualitative research was used to inventory and analyze data of Randai performance who were unable to compete in the realm of contemporary performing arts as well as inventory and analyze data, especially the elements of the performance that will be used in the development of the Minangkabau theatrical dance. Experimental research was used to create innovative dance that refers to the results of the first phase of research. This research uses an interdisciplinary approach (sociology /anthropology of dance and music, theater, choreography/dance composition, as well as the artistic performances). The result of the research will be able to open a new discourse on Minangkabau contemporary performing arts. The presentation of this article is based on the results of the first phase of research.
\end{abstract}

\section{Keywords: Randai , Innovative Dance, Elements of Randai Performing Art}

\section{INTRODUCTION}

Traditional Minangkabau performing arts are still used and functioned by Minangkabau people in West Sumatra. Traditional dance and music performances, for example, are used in various events, and activities that are both customary, socio-cultural and entertainment industry. Minangkabau performing arts are also displayed in various star hotels, tourist areas, and entertainment shows.

Developments in tourism sector have triggered the growth of entertainment and tourism industry in Indonesia in general and West Sumatra in particular. The emergence of the entertainment industry, has led to the formation of various event organizers and art galleries that grow like 'mushrooms' in the city of Padang and Bukit Tinggi and Padang Panjang and other cities in West Sumatra.

The growth of the performing arts industry also gave rise to competitive competition between traditional and modern art or creative arts. Competition is based on the quality of the performance, innovation arable or forms of performance and management of the performing arts. In addition, competition is also based on packaging innovations and the supply of dance arts, financial capacity of a production house to hires choreographers (dance creators), music stylists and fashion and professional artists to create innovative, quality and marketable dance works in the performing arts market.

The competitive competition between traditional performing arts and modern performing arts increasingly impacts the exclusion of Minangkabau traditional performing arts, such as Minangkabau traditional music and dance, and Randai . Their existence is pressured by the splendor and quality of modern performing art that are more patterned and well packaged. As a result, traditional performing arts such as traditional dance and Randai which are still traditionally patterned are increasingly marginalized in the contemporary performing arts market. The development carried out on Randai performing art (baRandai ) is essentially "an effort to 'save' Randai traditional performing arts in contemporary performing arts by reprocess and modify Randai in a new form of performing art namely theatrical dance based on Randai performance."

Performing 'traditional Randai ' which is still original or traditional in terms of costumes, motion, acting and literature as well as blocking techniques, requires 
adjustments to the elements of contemporary performing arts, in order to get 'space' in the realm of contemporary performing arts. Maadis Research (2012: 18) found that Randai has not been able to adjust to the flow of the development of performing arts. The findings of this study indicate that Randai which is considered a comprehensive performance art has increasingly become less desirable by the community in many nagari (villages) in West Sumatra. Referring to Nerosti (2011: 89), the tendency of traditional art that takes too long and is not too 'neat' and repetitive motion design, causes less aesthetic response from the audience.

In the framework of developing Randai performance art to theatrical dance research is needed that will explore the potential of existing Randai performing arts such as the duration of the time, the pattern of movement, pat galembong and the music. The results of the study are used as a basis for working on it again in the form of new performing arts models in the form of theatrical dance with Randai patterns. It can also be an enrichment of inventory and creativity, as well as recreating traditional art and dance in the Minangkabau of West Sumatra, in the present and in the future.

\section{METHOD}

This research was designed using assumptions of qualitative research and experimental assumptions. Research conducted qualitatively (the first phase of research) and experimentally (the second phase of research). Qualitative research was used to inventory and analyze data of Randai performance who were unable to compete in the realm of contemporary performing arts as well as inventory and analyze data, especially the elements of the performance that will be used in the development of the Minangkabau theatrical dance. Experimental research was used to create innovative dance that refers to the results of the first phase of research. This research uses an interdisciplinary approach (sociology /anthropology of dance and music, theater, choreography/dance composition, as well as the artistic performances). Several methods were carried out including library studies, surveys and documentation studies. Meanwhile, to create innovative Minangkabau dance based on Randai was done through experimenting with the dance creation and construction methodology approach.

\section{RESULT AND DISCUSSION}

\section{Minangkabau Randai \\ Randai and its performance}

Randai is a traditional Minangkabau

Performing Arts that has long existed in the Minangkabau community even before Islam entered Minangkabau, and before most of the Minangkabau cultural territory became part of the administrative territory of the Republic of Indonesia. Randai grows and develops in the nagari community in Minangkabau, and is part of the sociocultural life of the nagari community.
Randai comes from the words "andai" or "handai" be'Randai -andai' (clumping) which means to speak using a 'kias,' 'like,' 'pantun' and the 'petatah petitih' (the proverbial saying). According to Yulfian Azrizal (1994: 71) Randai is: 'an art which is a 'pamainan anak nagari' of Minangkabau. A game with movements in a circle, then slowly small steps, while telling the story through 'singing' alternately." In the past some people of Minangkabau always interacted with 'bapantun' (rhyming), 'badendang' (chanting) or 'bakaba' (telling story, news). While bakaba and chanting some people move in tune with the strains of kaba and the chanting, there was a fusion of literature, dance and music (Maadis, 2002: 4). Randai conveys the messages in kaba, both related to events about the Minangkabau, the history of the origin of the Minangkabau people and their customs. In kaba also inserted messages in the form of advice about the problems of life both in the world and the hereafter (Djamal, 2002: 12).

According to Ismar Maadis (2008: 24), Randai originates from the activities of young people in the martial arts academy (telling stories like gurindam), with kaba, the youths convey various purposes and events that are around or preach the contents of tambo. This activities continue in the community and among young people in surau and in 'Sasaran Pencak Silat' (martial arts academy). In further developments, the kaba is delivered in the form of 'irama dendang' (chanting), accompanied by musical instruments such as bansi and saluang. Because Randai develops within the 'sasaran pencak silat' (martial arts academy), Randai also incorporates pencak movements, as an integrated part in Randai. In another version, Khairul Harun (1992: 72) says that Randai begins with the "Randai Dance" in which a group of people while circling moves by following dampeang (dendang). Each dampeang directs the form of motion that will be performed by the dancers. Dancers intended in this context are 'anak Randai ' or dubalang or 'pesilat' (the silat fighter).

Every performance of Randai, always starts with an initial offering in the step motion art of 'silat galombang,' followed by a 'siriah carano' by one or two female performers in front of the audience represented by community leaders present. After serving betel in carano, followed by the delivery of words by janang in the form of traditional speech. After the introductory customary speech is finished, Randai starts with the delivery of the opening chanting called simarantang. The duration of the show is unlimited, and usually depends on the wishes or timeliness set by the performers. Randai can last for 2 or 3 hours, even 5 hours for one night. The performance can continue for 3 to 7 consecutive nights, depending on the ability of the performers and the organizer of the Randai performance itself. The audience becomes part of the Randai performance where their merges, interacts, and melts into the atmosphere, around the Randai circle, while maintaining a distance from the Randai players so as not to interfere with the smooth running of the Randai performance. 


\section{The development of Randai became a form of theater}

Early Randai developed into a form of 'theater' allegedly since the establishment of the 'Sekolah Radja' (King's School) in Bukittinggi in the early 19th century which enabled the development of 'teater bangsawan' (aristocratic theater) in Minangkabau. The aristocratic theater had stimulated the Minangkabau Randai performance artists at that time to include elements of play, scenes and dialogues in the Randai performance. Furthermore, Randai which has been transformed into a folk theater in its performance conveys kaba or tells an event in dialogue using actors, where through dialogue between messages the story is conveyed to the audience. The move from one scene to the next or the introduction of the problem to the next problem is explained with a chant sung by a 'tukang dendang.' The transition in moving scenes is emphasized by the pencak dance movement, where the motion reflects the problems that will be conveyed in the next scene.

The development of Randai performance art into a traditional theater was also possible because of the love of the niniak mamak towards theatrical or aristocratic theater. This new form of Randai is being cultivated by the Minangkabau people, both in the villages that are in Luhak (darek) and in villages that are in 'rantau,' areas such as Pariaman, Banda Sapuluah (South Pesisir area). The Randai we see now is a folk theater that has been entrenched and has become a traditional art for the Minangkabau people.

\section{The form and content of the Randai performance The structure of Randai performance}

Randai performance as a folk theater contains stories conveyed through dialogue and acting, pancak movements, and kaba that is chanted. The structure of Randai performance consists of: (1) Silek Galombang, (2) Pasambah, (3) the course of a series of stories with various dialogues and accompaniment of chanting, (4) legaran that plays pancak movements, (5) acting, and (6) closing with closing sambah.

\section{Design pattern and procedures of the performance \\ Randai performance structure is manifested} into a folk theater performance art with patterns of work and procedures that have been designed. The performance starts with galombang movements, followed by 'dendang dayang daini,' and there must be a legaran, and each motion in the legaran is pancak motion, usually according to the silat school from their respective nagari. Motion acts as a translator or introduction to the scene of the story that will be played by the character for the next scene, pat galembong is only a "q" or the code will end the movement of pancak in legaran.

Every Randai must use a dendang simarantang randah and simarantang tinggi. Usually simarantang tinggi is used to end the Randai performance. If one of these requirements has not been met, it means that the performance has not been considered as a Randai performance. Silek galombang is an opening of performances, by paying respect to the guests and the silek master or called the grandmaster (maha guru) or the ninak mamak. Silek galombang is a picture of the social life of the community, and is reflected in the surging movements of pancak in the low, medium and high range of motion. Corrugated pancak movements are taken from the basics of silat or pencak silat movements from the sasaran pencak silat in the nagari.

Galombang and Pencak Silat martial arts movements are performed in a circular or circular configuration that rotates against the clockwise direction, or in the direction of the rotation of Muslims who are circling the Ka'bah, in performing Hajj and Umrah worship. Each motion in the circulation corresponds to the story that will be presented for the next round. Legaran or movement in legaran functions as an introduction or description of the story that will be delivered by the Randai players in their cast or dialogue in the next round. Silat motion or pancak motion or a combination of both, becomes a 'connecting bridge' between round after round. The end of the pancak movement is the 'tapuak galembong' or endong/palam (Indrayuda (2009: 32).

\section{Acting and actor in acting out the character of the story in the Randai script. \\ If Randai plays the "Cindua Mato" script, then} in the Randai performance there must be a cast of the characters "Cindua Mato" and "Puti Bungsu." In this role the dialogue is carried out between the characters and other characters.

Sambah penutup

The Randai is closed by sambah penutup which is performed with the closing galombang motion. The closing galombang motion is accompanied by the 'salam pasambahan' and 'dendang simarantang tinggi.' This is a sign that Randai 's performance has ended. At the end of the performance, the talempong and 'gandang' (drum instruments) were sounded.

Analysis and identification

Analysis and identification include aspects that are unable to compete in the realm of performing arts, namely;

1.The form and content of Randai performances, which need to be adjusted to the context of contemporary performing arts

2.Randai 's presentation structure must still be adjusted to the artistic and aesthetic value of contemporary performing art

3.Cultivation patterns and procedures for Randai performances which often cause boredom of the audience and weaken the uniqueness of Randai itself

4.Variety of movements, music, acting, costumes and literature in Randai performance arts that do not yet contain elements of novelty and entertainment.

The results of the analysis and identification can be seen in the table below. 
Table. 1. Aspects of the Randai that less in Competition in the Performing Arts Industry

\begin{tabular}{|c|c|c|c|c|c|}
\hline \multirow[t]{2}{*}{ No } & \multicolumn{5}{|c|}{ Aspects } \\
\hline & Form & Content & Structure & Composition & Performing Technic \\
\hline 1 & $\begin{array}{l}\text { The } \\
\text { motives } \\
\text { that are } \\
\text { still often } \\
\text { repetitive }\end{array}$ & $\begin{array}{l}\text { The contents are } \\
\text { often too revealing } \\
\text { stories of past } \\
\text { human life stories }\end{array}$ & $\begin{array}{l}\text { The structure is too } \\
\text { easy to read by the } \\
\text { audience }\end{array}$ & $\begin{array}{l}\text { Patterns are always } \\
\text { forced to make the } \\
\text { tapuak galembong } \\
\text { element more } \\
\text { dominan }\end{array}$ & $\begin{array}{l}\text { The way the show is still using } \\
\text { the addition pattern }\end{array}$ \\
\hline 2 & $\begin{array}{l}\text { The less } \\
\text { aesthetic } \\
\text { and artistic } \\
\text { attitude of } \\
\text { dance }\end{array}$ & $\begin{array}{l}\text { The content has } \\
\text { rarely been } \\
\text { conveyed without } \\
\text { the distinctive } \\
\text { expression of the } \\
\text { randai performance } \\
\text { art }\end{array}$ & $\begin{array}{l}\text { The structure of the } \\
\text { show is sometimes } \\
\text { not neat }\end{array}$ & $\begin{array}{l}\text { The pattern does not } \\
\text { include the elements } \\
\text { of pencak silat in his } \\
\text { work }\end{array}$ & $\begin{array}{l}\text { The show method still uses the } \\
\text { galombang movement and } \\
\text { talempong pacik at the } \\
\text { beginning of the enterer arena }\end{array}$ \\
\hline 3 & $\begin{array}{l}\text { Sobering } \\
\text { costumes } \\
\text { that seem } \\
\text { 'slum' and } \\
\text { old }\end{array}$ & $\begin{array}{l}\text { The contents are } \\
\text { less conveyed with } \\
\text { literature, so many } \\
\text { vowels are } \\
\text { improperly }\end{array}$ & $\begin{array}{l}\text { The structure of the } \\
\text { show has not been } \\
\text { able to develop in an } \\
\text { innovative direction }\end{array}$ & $\begin{array}{l}\text { The pattern of } \\
\text { working in groups is } \\
\text { not yet exploited }\end{array}$ & $\begin{array}{l}\text { as an expression of performing } \\
\text { arts closing with the galombang } \\
\text { movement or talempong pacik }\end{array}$ \\
\hline 4 & $\begin{array}{l}\text { Cosmetolo } \\
\text { gy that is } \\
\text { not neatly } \\
\text { arranged, } \\
\text { and lacks } \\
\text { make-up }\end{array}$ & & $\begin{array}{l}\text { Structure is too } \\
\text { standard }\end{array}$ & $\begin{array}{l}\text { The pattern of } \\
\text { working on groups is } \\
\text { not worked out either } \\
\text { from the aspect of } \\
\text { contrast, uniti, and } \\
\text { broken in various } \\
\text { variations }\end{array}$ & $\begin{array}{l}\text { There are still no variations and } \\
\text { modifications in the procedures } \\
\text { of the show }\end{array}$ \\
\hline
\end{tabular}

\section{CONCLUSION}

\section{Strengths and weaknesses}

Randai as an element of art contained in it has advantages that have the potential to be developed into performing arts that meet the demands and current situation. However, if examined from the side of the form and content of the art of randai, the structure of the presentation of the art of randai and artistic and aesthetic values traditionally has weaknesses from the context of modern performing arts. The form and content, structure and artistic and aesthetic values no longer fit the tastes of the contemporary performing arts community and have not been oriented towards the entertainment industry. The pattern of work and procedures for performing arts, including the variety of movements, music, acting, costumes and literature in the Minangkabau traditional randai performing arts, still do not contain elements of renewal and entertainment elements. This raises the audience's boredom and obscures the uniqueness of the randai itself.

Even so, if viewed from the strengths and values of art contained in the randai, opportunities for development are opened to meet the demands of contemporary entertainment. The potential for development mainly includes aspects that are competing in the realm of performance, namely;

1.The form and content of Randai art, which has problems from the context of contemporary performing arts.

2.The structure of the presentation of the Minangkabau tradition of Randai art which has artistic and aesthetic value in accordance with the tastes of today's performing arts community and which has not been oriented to the entertainment industry.

3.Working patterns and procedures for performing Randai arts that eliminate audience boredom and weaken the uniqueness of the randai itself.

4.A variety of movements, music, acting, costumes and literature in the performing arts of the Rangkang Minangkabau tradition which contain elements of renewal and elements of entertainment.

On the basis of this development, later designed a randaibased dance theater design.

\section{REFERENCES}

[1] Indrayuda. 2009. "Peran Elit Adat dalam Keberlangsungan Tari Minangkabau”. Jurnal Pendidikan dan Kebudayaan Balitbang Depdiknas Jakarta.Vol. 15 Nomor 2 Maret 2009.

[2] Jamal. Emral. 2011. Keberadaan Perempuan di Rumah Gadang. Padang: Yayasan Salimbado.

[3] Jamal. Emral. 2002 . "Karya Sastra Sebagai Sumber Sejarah: Sebuah Pembicaraan Awal Tentang Karya Sastra Sejarah Batang Kebudayaan Melayu Minangkabau" Sastra Bung Hatta Vol. 1 Tahun 2002

[4] Khairul Harun. 1992. Kesenian Randai Di Minangkabau. Jakarta: Gramedia.

[5] Maadis, Ismar. 2012. Reposisi Kesenian Randai Sebagai Seni Pertunjukan Rakyat Minangkabau 
dalam Kehidupan Berbudaya Masa Kini. Padang: LKAAM Sumbar.

[6] Maadis, Ismar. 2008. Risalah Kubuang Tigo Baleh, Solok: Pangulu/Ampek Jinih 'nan basaluak deta ba cincin' Jakarta: Bintang Grafika

[7] Nerosti. 2011. "Perubahan Tari Minangkabau dalam Masyarakat Perkotaan di Sumatera Barat". Tanjung Malim : Universiti Pendidikan Sultan Idris Malaysia.

[8] Yulfian Azrizal. 1994. Keterampilan Tradisional Minangkabau: Kurikulum Muatan Lokal Sumatera Barat 1994 Untuk SLTP. Padang: Angkasa Raya. 